\title{
Edible Microorganisms-An Overlooked Technology Option to Counteract Agricultural Expansion
}

\author{
Tomas Linder* \\ Department of Molecular Sciences, Swedish University of Agricultural Sciences, Uppsala, Sweden
}

Keywords: carbon capture, Fermi problem, land sparing, single-cell protein, sustainable intensification

\section{MICROBIAL ALTERNATIVES TO CONVENTIONAL SOURCES OF FOOD AND FEED}

OPEN ACCESS

Edited by:

Ngonidzashe Chirinda, International Center for Tropical Agriculture (CIAT), Colombia

Reviewed by:

Dave Reay,

University of Edinburgh

United Kingdom

*Correspondence:

Tomas Linder

tomas.linder@slu.se

Specialty section

This article was submitted to Climate-Smart Food Systems,

a section of the journal

Frontiers in Sustainable Food Systems

Received: 19 March 2019

Accepted: 23 April 2019

Published: 08 May 2019

Citation:

Linder T (2019) Edible

Microorganisms - An Overlooked Technology Option to Counteract

Agricultural Expansion.

Front. Sustain. Food Syst. 3:32. doi: 10.3389/fsufs.2019.00032
The struggle to feed a growing human population while simultaneously halting or even reversing the conversion of natural habitat to agricultural land has become one of the defining challenges of the twenty-first century. Tropical rainforests are particularly at risk from habitat destruction as equatorial nations are expected to show some of the highest rates of population growth during this century (Laurance et al., 2014). However, even in the absence of population growth, tropical rainforests are already at risk from sudden shifts in trade patterns. A recent comment published in Nature (Fuchs et al., 2019) warns that Chinese tariffs on imported US soybeans, which were imposed as a result of the ongoing US-China trade war, will likely lead to massive destruction of Amazon rainforest as Brazil expands soybean production to meet Chinese demand for soybean imports.

Edible microbial biomass as an alternative to conventional sources of food and feed is a promising technology option to prevent habitat destruction caused by increases in food demand. Microorganisms such as bacteria, yeasts, and filamentous fungi have several beneficial properties including their rapid growth rate and their ability to assimilate simple organic substrates such as hydrocarbons, alcohols or organic acids (Linder, 2019). Microbial biomass has high protein content and often contains beneficial lipids and vitamins (Ritala et al., 2017). Industrial-scale production of edible microorganisms does not require arable land and consequently these types of facilities can be located on marginal lands or even more extreme environments such as dry arid regions. Intuitively one would also expect that large three-dimensional microbial cultivation systems (10-1000 $\mathrm{m}^{3}$ bioreactors) would enable more efficient land use. However, the cultivation of heterotrophic microorganisms (i.e., those that cannot themselves directly fix $\mathrm{CO}_{2}$ ) requires an organic feedstock, which must be sourced off-site. If these organic feedstocks in turn are derived from plant biomass, this would ultimately limit the land sparing potential of edible microbial biomass since land would still have to be set aside for feedstock production. An alternative approach would be to instead make use of recent developments in $\mathrm{CO}_{2}$ capture and conversion technologies to produce simple organic feedstocks (e.g., methane, methanol, formic acid, acetic acid) directly from atmospheric $\mathrm{CO}_{2}$ without any requirement for photosynthesis (Linder, 2019). 


\section{THE LAND SPARING POTENTIAL OF EDIBLE MICROBIAL BIOMASS AS A FERMI PROBLEM}

As there are currently no commercial large-scale industrial facilities converting atmospheric $\mathrm{CO}_{2}$ into edible microbial biomass, could the area requirements for the complete $\mathrm{CO}_{2}$-tomicrobial biomass process infrastructure be approximated to the nearest order of magnitude based on already available data? A Fermi problem (named after the Italian physicist Enrico Fermi) is a useful tool to make such preliminary approximations of unknown quantities to the nearest order of magnitude based on justified estimates. In the present case, there are in fact publicly available productivity values for (1) a now demolished large-scale commercial microbial feed plant in the United Kingdom, (2) a medium-scale commercial $\mathrm{CO}_{2}$-to-methanol conversion plant in Iceland, and (3) a pilot-scale $\mathrm{CO}_{2}$-capture facility in Canada.

Imperial Chemical Industries (ICI) initiated a microbial feed project in the late 1960s that resulted in the development of the microbial feed product Pruteen, which was derived from the methanol-assimilating bacterium Methylophilus methylotrophus (Vasey and Powell, 1984). M. methylotrophus biomass was reported to have a crude dry weight protein content of $72 \%$ and also contain several B vitamins (McNairney, 1984). In 1979, a $600 \mathrm{t}$ bioreactor with a working volume of $1500 \mathrm{~m}^{3}$ was installed at the ICI Pruteen factory in Billingham in the northeast of England (Bungard, 1992). The ICI Pruteen bioreactor was $60 \mathrm{~m}$ tall with a maximum internal diameter of $11 \mathrm{~m}$ and an annual productivity of $50000-60000 \mathrm{t}$ dry bacterial biomass to be used as animal feed (Westlake, 1986). Ultimately the production of Pruteen was discontinued in the late 1980s due to rising methanol prices and competition from soy-based feeds (Bungard, 1992). Assuming that the exterior of the ICI bioreactor would require some additional space for piping, I estimate the land area requirement for such a bioreactor to be $15 \mathrm{~m} \times 15 \mathrm{~m}=225 \mathrm{~m}^{2}$.

The George Olah methanol plant in Svartsengi, Iceland, produces methanol from concentrated geological $\mathrm{CO}_{2}$ emissions derived from a nearby geothermal power plant (Olah, 2013). The company Carbon Recycling International (CRI), which owns the methanol plant, reports an annual productivity of 5 million liters $=5000 \mathrm{~m}^{3}$ of methanol from a total of $5500 \mathrm{t} \mathrm{CO}_{2}$ (http:// www.carbonrecycling.is/george-olah). The density of methanol is $792 \mathrm{~g} / \mathrm{l}=0.792 \mathrm{t} / \mathrm{m}^{3}$ at room temperature, which would translate to an annual output of $5000 \mathrm{~m}^{3} \times 0.792 \mathrm{t} / \mathrm{m}^{3}=$ 3960 t methanol. I estimate the CRI George Olah methanol plant to occupy an area of $50 \mathrm{~m} \times 50 \mathrm{~m}=2500 \mathrm{~m}^{2}$ based on publicly available satellite images (Google Maps, coordinates $63^{\circ} 52^{\prime} 36.5^{\prime \prime} \mathrm{N} 22^{\circ} 25^{\prime} 25.0^{\prime \prime} \mathrm{W}$ ).

In the absence of concentrated $\mathrm{CO}_{2}$ sources such as flue gas, atmospheric $\mathrm{CO}_{2}$ will need to be extracted from ambient air by so-called direct air capture (DAC). The Canadian company Carbon Engineering (CE) has built a pilot $\mathrm{CO}_{2}$-capture facility in Squamish, British Columbia, which is reported to capture $1 \mathrm{t}$ $\mathrm{CO}_{2} / \mathrm{d}$ from ambient air (Keith et al., 2018). I estimate the CE pilot $\mathrm{CO}_{2}$-capture facility to occupy an area of $12.5 \mathrm{~m} \times 5 \mathrm{~m}$
$=62.5 \mathrm{~m}^{2}$ based on publicly available satellite images (Google Maps, coordinates $49^{\circ} 41^{\prime} 13.4^{\prime \prime} \mathrm{N} 123^{\circ} 09^{\prime} 44.0^{\prime \prime} \mathrm{W}$ ).

The reported yield coefficient for $M$. methylotrophus is $0.52 \mathrm{~g}$ dry bacterial biomass $/ \mathrm{g}$ methanol (Vasey and Powell, 1984). Hence, a total of $50000 \mathrm{t} / 0.52 \approx$ $96154 \mathrm{t}$ of methanol would be needed to produce $50000 \mathrm{t}$ dry M. methylotrophus biomass. Each ICI-type bioreactor would therefore require the equivalent of at least 25 CRI-type methanol plants $(96154 \mathrm{t} / 3960 \mathrm{t}=24.2813 \ldots)$. Each CRI-type methanol plant would in turn require at least $16 \mathrm{CE}$ type $\mathrm{CO}_{2}$-capture facilities $(5500 \mathrm{t} /[1 \mathrm{t} / \mathrm{d} \times 365 \mathrm{~d}]=15.0684 \ldots)$. It now becomes possible to approximate how many industrial facilities that would be required to replace conventional sources of protein such as soybean in a major economy like the US.

In 2017, US farmers planted soybeans over an area of 36 479570 ha with a total harvest of $119518490 \mathrm{t}$ (USDA, 2018). To produce an equivalent amount of dry bacterial biomass (ignoring for the moment that the soybean harvest is reported in wet weight) would therefore require $119518490 \mathrm{t} / 50000 \mathrm{t}$ $\approx 2390$ ICI-type bioreactors; $2390 \times 25=59750$ CRItype methanol plants; and $59750 \times 16=956000$ CE-type $\mathrm{CO}_{2}$-capture facilities. How much area would these facilities occupy as compared to the agricultural land required for soybean production? ICI-type bioreactors would require $2390 \times 225 \mathrm{~m}^{2}$ $=537750 \mathrm{~m}^{2} \approx 53.8$ ha; CRI-type methanol plants would require $59750 \times 2500 \mathrm{~m}^{2}=149375000 \mathrm{~m}^{2}=14937.5$ ha; and CEtype $\mathrm{CO}_{2}$-capture facilities would require $956000 \times 62.5 \mathrm{~m}^{2}=$ $59750000 \mathrm{~m}^{2}=5975$ ha. Hence, the combined surface area required for $\mathrm{CO}_{2}$ capture, conversion, and bacterial cultivation thus adds up to $53.8 \mathrm{ha}+14937.5 \mathrm{ha}+5975 \mathrm{ha}=20966.3 \mathrm{ha}$. This corresponds to $(20966.3 \mathrm{ha} / 36479570 \mathrm{ha}) \times 100 \% \approx 0.06 \%$ of the area of US agricultural land that was planted with soybeans in 2017. This number will become even smaller when correcting for wet vs. dry weight. To put this amount of land area in context, 20966.3 ha is less than half the land area of the Pacific island of Guam (54 390 ha).

There would obviously be additional land area requirements for the production of microbial biomass at this scale, which includes industrial infrastructure for harvesting and drying the bacterial biomass as well as the treatment of any industrial wastewater that cannot be recycled. Conversely, concentrated $\mathrm{CO}_{2}$ in the exhaust gases from the bioreactors (derived from bacterial respiration of approximately half of the methanol feedstock that is not converted into biomass) can be directly captured on site and re-converted to methanol, which would decrease the overall requirement for DAC facilities.

There would also be a requirement for large-scale ammonia production facilities (ideally powered by zero emission technologies) to satisfy the nitrogen requirements of the cultivated bacteria. Another outstanding question is the energy demand for each type of facility, which would have to be met by the requisite power generation facilities with their corresponding land area requirements. It should be noted that photovoltaic panels could be placed on top of all the three types of facilities from $\mathrm{CO}_{2}$ capture to bacterial cultivation, although the total 
energy generation capacity would be unlikely to satisfy the total energy demand. It would also seem feasible to integrate wind turbines with lower standing structures such as the CE-type $\mathrm{CO}_{2}$-capture facilities.

\section{POSSIBILITIES AND CAVEATS}

The simplified calculation shown above demonstrates that it is at least theoretically possible to reduce the surface area requirements for some forms of food and feed production by up to three orders of magnitude using already existing technologies. Even if the final approximation would underestimate the land area requirements for $\mathrm{CO}_{2}$ capture, conversion and bacterial cultivation by an order of magnitude, this would still correspond to $<1 \%$ of the surface area required to produce the equivalent amount of feed protein through conventional soybean cultivation. This in turn would enable large-scale restoration of agricultural lands to their original habitats-either forests or grasslands, which would not only benefit biodiversity preservation but could also be used for carbon sequestration (Silver et al., 2000; Nave et al., 2018; Yang et al., 2019). However, such an approach would need to be carefully evaluated to determine whether any net negative emissions gained from large-scale land sparing risk being offset by the embedded carbon footprint of the necessary industrial infrastructure in addition to any emissions associated with its energy consumption. The current literature on the environmental footprint of microbial sources of food and feed have focused on processes that use feedstocks derived from either agriculture or natural gas (see for instance Smetana et al., 2015; Pikaar et al., 2018; Couture et al., 2019). Additional studies are necessary to evaluate emissions and other environmental costs of microbial feed and food production processes that employ direct $\mathrm{CO}_{2}$ capture and conversion as the process described above.

\section{REFERENCES}

Bungard, S. J. (1992). Bugs in the works - biology at ICI Billingham. J. Biol. Educ. $26,252-256$

Couture, J. L., Geyer, R., Hansen, J. Ø., Kuczenski, B., Øverland, M., Palazzo, J., et al. (2019). Environmental benefits of novel nonhuman food inputs to salmon feeds. Environ. Sci. Technol. 53, 1967-1975. doi: 10.1021/acs.est. 8 b03832

Fuchs, R., Brown, C., Cossar, F., Henry, R. C., and Rounsevell, M. (2019). Why the US-China trade war spells disaster for the Amazon? Nature 576, 451-454. doi: 10.1038/d41586-019-00896-2

Keith, D. W., Holmes, G., St. Angelo, D., and Heidel, K. (2018). A process for capturing $\mathrm{CO}_{2}$ from the atmosphere. Joule 2, 1573-1594. doi: 10.1016/ j.joule.2018.05.006

Laurance, W. F., Sayer, J., and Cassman, K. G. (2014). Agricultural expansion and its impacts on tropical nature. Trends Ecol. Evol. 29, 107-116. doi: $10.1016 /$ j.tree.2013.12.001

Linder, T. (2019). Making the case for edible microorganisms as an integral part of a more sustainable and resilient food production system. Food Sec. In press. doi: 10.1007/s12571-019-00912-3. [Epub ahead of print].

McNairney, J. (1984). Modification of a novel protein product. J. Chem. Tech. Biotechnol. 34B, 206-214.
Industrial-scale bioreactors, methanol conversion plants and $\mathrm{CO}_{2}$-capture infrastructure also require significant capital investments but many of the developing economies in the tropics are highly unlikely to prioritize such initiatives without external financial support. Any policy efforts to implement medium- to large-scale substitution of conventional food and feed products with microbial alternatives must also take into account the many inherent complexities of the current global food system or risk unintended societal consequences. Edible microbial biomass will also be unlikely to effectively compete with conventional sources of food and feed unless the environmental costs of their production (habitat loss, $\mathrm{CO}_{2}$ emissions, fresh water use, soil degradation etc.) are somehow factored into the price of the final food product (Fuchs et al., 2019).

The purpose of this opinion article is ultimately to demonstrate that with current technologies there are no longer explicit biophysical barriers that prevent a radical reduction in the geographical footprint of global food production. Whether such technologies could also translate into a reduction in the overall environmental footprint of food production while simultaneously addressing food-related societal issues such as hunger, malnutrition, and poverty will depend on policy choices made in how such technologies are implemented. It is vital that new technology options such as edible microbial biomass produced independently of photosynthesis are not simply dismissed out of hand as "techno-optimism." But it is also essential that any efforts to implement these technologies are executed in a holistic and considerate fashion.

\section{AUTHOR CONTRIBUTIONS}

The author confirms being the sole contributor of this work and has approved it for publication.

Nave, L. E., Domke, G. M., Hofmeister, K. L., Mishra, U., Perry, C. H., Walters B. F., et al. (2018). Reforestation can sequester two petagrams of carbon in US topsoils in a century. Proc. Natl. Acad. Sci. U.S.A. 115, 2776-2781. doi: $10.1073 /$ pnas.1719685115

Olah, G. A. (2013). Towards oil independence through renewable methanol chemistry. Angew. Chem. Int. Ed. Engl. 52, 104-107. doi: 10.1002/anie.201204995

Pikaar, I., Matassa, S., Bodirsky, B. L., Weindl, I., Humpenöder, F., Rabaey, K., et al. (2018). Decoupling livestock from land use through industrial feed production pathways. Environ. Sci. Technol. 52, 7351-7359. doi: 10.1021/acs.est.8b00216

Ritala, A., Häkkinen, S. T., Toivari, M., and Wiebe, M. G. (2017). Single cell protein-state-of-the-art, industrial landscape and patents 2001-2016. Front. Microbiol. 8:2009. doi: 10.3389/ fmicb.2017.02009

Silver, W. L., Ostertag, R., and Lugo, A. E. (2000). The potential for carbon sequestration through reforestation of abandoned tropical agricultural and pasture lands. Restor. Ecol. 8, 394-407. doi: 10.1046/ j.1526-100x.2000.80054.x

Smetana, S., Mathys, A., Knoch, A., and Heinz, V. (2015). Meat alternatives - life cycle assessment of most known meat substitutes. Int. J. Life Cycle Assess. 20, 1254-1267. doi: 10.1007/ s11367-015-0931-6 
USDA (2018). Crop Production, September 12, 2018. National Agricultural Statistics Service (NASS), Agricultural Statistics Board, United States Department of Agriculture.

Vasey, R. B., and Powell, K. A. (1984). Single-cell protein. Biotechnol. Genet. Eng. Rev. 2, 285-311.

Westlake, R. (1986). Large-scale continuous production of single cell protein. Chem. Ing. Tech. 58, 934-937.

Yang, Y., Tilman, D., Furey, G., and Lehman, C. (2019). Soil carbon sequestration accelerated by restoration of grassland biodiversity. Nat. Commun. 10, 718. doi: 10.1038/s41467-019-08636-w
Conflict of Interest Statement: The author declares that the research was conducted in the absence of any commercial or financial relationships that could be construed as a potential conflict of interest.

Copyright (c) 2019 Linder. This is an open-access article distributed under the terms of the Creative Commons Attribution License (CC BY). The use, distribution or reproduction in other forums is permitted, provided the original author(s) and the copyright owner(s) are credited and that the original publication in this journal is cited, in accordance with accepted academic practice. No use, distribution or reproduction is permitted which does not comply with these terms. 